\title{
¿Es posible incrementar la motivación por oportunidad de los inmigrantes emprendedores en Europa?
}

\author{
Antonia M. García-Cabrera ${ }^{1 \mathrm{a}}$, Ana M. Lucía-Casademunt ${ }^{\mathrm{b}}$, Laura Padilla-Angulo ${ }^{\mathrm{c}}$ \\ ${ }^{a}$ Universidad de Las Palmas de Gran Canaria, España \\ ${ }^{b}$ Universidad de Málaga \\ ${ }^{c}$ Universidad Loyola Andalucia
}

doi: $10.20420 /$ eni.2020.367

\begin{abstract}
Resumen
El presente estudio analiza los factores que condicionan la motivación por oportunidad del inmigrante emprendedor establecido en 31 países europeos. El trabajo identifica que la distancia lingüística existente entre los países de residencia y de origen del inmigrante socava su motivación emprendedora por oportunidad. Al mismo tiempo, el trabajo encuentra que la motivación por oportunidad del inmigrante emprendedor aumenta cuando: (1) la cultura del país de acogida se caracteriza por la presencia de valores culturales de elevada aversión a la incertidumbre, que habitualmente reduce el comportamiento emprendedor de la población local; y (2) las leyes y regulaciones vigentes en su país de origen y su país residencia difieren (distancia regulativa). Del trabajo derivan implicaciones para la formulación de políticas públicas y actuación de asociaciones privadas para promover la motivación por oportunidad del inmigrante emprendedor.
\end{abstract}

Palabras clave: emprendedor inmigrante, instituciones, distancia institucional, desventajas del extranjero.

Clasificación JEL: J61, M13, M16.

Agradecimiento: Los autores agradecen el apoyo financiero proporcionado por el Ministerio de Economía y Competitividad [proyecto ECO2016-80518-R].

Fuente de referencia: García-Cabrera, A.M., Lucía-Casademunt, A.M., \& Padilla-Angulo, L. (2020). Immigrants' entrepreneurial motivation in Europe: liabilities and assets. International Journal of Entrepreneurial Behavior \& Research, 25(8), 1707-1737.

\section{Introducción}

El emprendimiento llevado a cabo por los inmigrantes ha sido asociado habitualmente a una motivación por necesidad, de manera que éstos considerarían la opción de crear una empresa solo por ser menos dificultosa para ellos que la de conseguir un empleo por cuenta ajena. Sin embargo, también existen inmigrantes con motivación emprendedora por oportunidad que, apoyándose en su preferencia o apuesta personal, tratan de identificar y explotar oportunidades empresariales. Ambos tipos de motivadores (necesidad y oportunidad) pueden estar simultáneamente presentes en la motivación emprendedora del individuo (Williams, 2009). Ahora bien, como es la motivación por oportunidad la que principalmente se asocia al crecimiento económico y a la generación de riqueza en los países desarrollados (Reynolds y otros, 2002), es de interés conocer y comprender los factores que condicionan la motivación por oportunidad de los inmigrantes.

La mayoría de las investigaciones que indagan sobre el emprendimiento de los inmigrantes se han centrado en el análisis de cuestiones de nivel micro, concernientes a los individuos, de manera que apenas se conoce cómo otras variables de nivel meso y macro condicionan la motivación y decisión emprendedoras del inmigrante. Con el ánimo de cubrir esta laguna existente, el presente trabajo analiza la influencia que sobre la motivación emprendedora de los inmigrantes tiene: (1) variables de nivel macro, tales como la distancia institucional entre los países de residencia y de origen del inmigrante (en concreto, las distancias

${ }^{1}$ Autor de correspondencia: antonia.garcia@ulpgc.es 
lingüística y regulativa), así como aspectos institucionales del país de acogida del inmigrante (en particular, el índice de facilidad para realizar negocios y los valores culturales de aversión a la incertidumbre); (2) variables de nivel meso, tales como las conexiones sociales del emprendedor inmigrante; y (3) variables de nivel micro, entre ellas la actitud emprendedora personal, o la autoeficacia emprendedora percibida (esto es, el control de comportamiento percibido). Los resultados del estudio muestran el papel clave que los factores de nivel macro, particularmente las distancias regulativa y lingüística, así como la cultura del país de acogida, juegan en la motivación emprendedora de los inmigrantes en Europa.

\section{Marco teórico}

Las instituciones vigentes en un país pueden condicionar la motivación emprendedora de los individuos residentes en tal país al facilitar o dificultar la identificación y explotación de oportunidades empresariales (Stenholm y otros, 2013). Por ejemplo, si los individuos perciben la existencia de instituciones adecuadas para la práctica empresarial, probablemente incrementarán su motivación por oportunidad. Atendiendo a ello, defendemos que para comprender los factores que causan la motivación emprendedora de los inmigrantes, es necesario considerar no sólo variables de nivel micro relacionadas con las características del propio individuo y variables de nivel meso relativas a su conexión e interacciones sociales, sino variables de nivel macro concernientes al país en el que se establecen para residir.

Con respecto a las variables de nivel micro, creemos que los inmigrantes con alto control de comportamiento percibido, esto es, con elevado concepto personal de eficacia (Bandura, 1997) y confianza en sus propias capacidades y habilidades para ejercer el emprendimiento, así como con fuerte actitud emprendedora, esto es, que tienen el convencimiento de que el resultado de las acciones emprendedora que ellos acometieran serían deseables (Azjen, 1991), tendrán mayor motivación por oportunidad.

En lo que respecta a los factores de nivel meso, y basándonos en Kim, Wennberg y Croidieu (2016), sostenemos que el contexto social del que forma parte el inmigrante representa un conductor de su motivación emprendedora por oportunidad. Ello es así porque los individuos no son seres aislados, sino que están integrados en un "sistema relacional de interacciones entre individuos y comunidades" (Kroeber \& Parsons, 1958, p. 583), estando sus comportamientos, por tanto, condicionados por el sistema relacional del que forman parte. Por ejemplo, los inmigrantes, a través de su pertenencia asociaciones, pueden acceder a información útil sobre las leyes vigentes en el país en el que se asientan, los valores culturales que comparte la población local o las prácticas empresariales frecuentemente utilizadas. Esta información les permitiría identificar con mayor facilidad nichos emprendedores, creciendo por tanto su percepción de factibilidad de la acción emprendedora. Por consiguiente, cabría esperar que cuanto mayor es la participación de los inmigrantes en asociaciones, mayor será su motivación emprendedora por oportunidad.

En lo que se refiere a factores de nivel macro, y dado que el contexto institucional vigente en el país de destino influye en el desarrollo de las empresas creadas y/o establecidas en los mismos (ej. Stenholm y otros, 2013), incorporamos tales variables también en nuestro estudio. Scott (1995) distingue diferentes elementos en el contexto institucional, en particular los regulativos (leyes), los normativos (valores culturales) y los cognitivos (prácticas habitualmente utilizadas por las empresas). De esta forma, los individuos deben conocer los requerimientos institucionales de cada país y adaptar su comportamiento a ellos si desean alcanzar el éxito (Scott, 1995). Los inmigrantes, al estar establecidos en un país extranjero 
afrontan desventajas de la extranjería en el desarrollo de la actividad empresarial, en la medida que no conocen/comprenden tales aspectos institucionales (Mata \& Alves, 2018).

La distancia institucional, a este respecto, es la disimilitud o diferencia "entre las instituciones regulativas, cognitivas y normativas de dos países" (Kostova \& Zaheer, 1999, p. 71) y, en el ámbito empresarial, tal distancia repercute en la dificultad para que la información fluya de forma eficaz entre las personas radicadas en diferentes países (Brewer, 2007).

En primer lugar, la distancia regulativa hace referencia a las dificultades para familiarizarse con los sistemas administrativos, políticos o económicos del país de acogida, lo que condiciona la capacidad de los inmigrantes para conocer y comprender tal marco regulador (Brewer, 2007). En esta línea, Azmat (2010) sostiene que es probable que los inmigrantes emprendedores afronten dificultades para adaptarse a las leyes y regulaciones del país de acogida, especialmente si han estado expuestos a un entorno institucional débil en su país de origen (ej. si proceden de países en desarrollo, con marcos reguladores menos estables y sólidos). Sin embargo, cuando las leyes del país de residencia son similares a los del país de origen del inmigrante (ej. las leyes que regulan la actividad económica o la fiscalidad son similares), se reduce la asimetría de información que afrontan los inmigrantes en el país de acogida (Mata \& Alves, 2018) y, por tanto, también sus desventajas de extranjería. La menor distancia institucional regulativa provocará que el inmigrante vea tan factible y deseable la actividad emprendedora como lo hacen los locales, y ello tendrá un impacto positivo en su motivación por oportunidades.

En segundo lugar, la cultura (instituciones normativas) también difiere entre países (Hofstede, 1980) y, debido a ello, cabe también esperar que la mayor distancia entre países en lo que a valores culturales se refiere incremente las dificultades del inmigrante para adaptarse a las condiciones locales. A este respecto, algunos autores han encontrado que el uso de una lengua común reduce la distancia cultural dado que la lengua/idioma es parte de una cultura (Mariotti \& Piscitello, 1995). Atendiendo a ello, podemos esperar que cuanto menor sea la distancia entre el país de residencia de los inmigrantes y el país de origen en el idioma (en el caso más favorable, en todas las regiones del país de acogida la primera lengua es la del país de origen del inmigrante), mayor será la motivación por oportunidad del inmigrante.

Adicionalmente, y a pesar de que la extranjería representa una desventaja para la integración laboral de los inmigrantes, lo que provoca que funden empresas motivados por la necesidad en los países en que se asientan (como alternativa para lograr la subsistencia), algunos trabajos previos han descubierto que los extranjeros pueden fundar empresas motivados por razones de oportunidad en mayor medida que la población local. En nuestra opinión, esto puede ser debido a que los inmigrantes podrían ser más efectivos que la población local en la búsqueda de oportunidades emprendedores para ellos la condición de extranjería representaría un activo (Min \& Bozorgmehr, 2003)-. Atendiendo a ello, podríamos esperar que, aquellos inmigrantes que perciban la existencia de un entorno regulatorio favorable para los negocios en los países de acogida vean incrementada su motivación por oportunidad.

Finalmente, y en cuanto a la cultura nacional o valores sociales compartidos por la población en el país de acogida (los aspectos normativos de las instituciones), cabe reseñar que éstos también condicionan la motivación emprendedora de los individuos. Por ejemplo, las sociedades con un bajo nivel de aversión a la incertidumbre (es decir, que no temen situaciones inciertas o desconocidas), están en mayor medida preparadas para asumir riesgos $\mathrm{y}$, 
consecuentemente, para acometer actividades emprendedoras (Hofstede, 1980); sin embargo, las sociedades con un alto nivel de aversión a la incertidumbre temen en gran medida el fracaso y evitan asumir riesgos. Atendiendo a ello, creemos que cuando la cultura nacional del país de acogida perjudica la motivación emprendedora por oportunidad, los inmigrantes, en comparación con los locales, y debido precisamente a su condición de extranjeros, estarán relativamente aislados del estímulo negativo de tal entorno cultural (Contín-Pilart \& Larraza-Kintana, 2015). De esta forma, podrán identificar oportunidades emprendedoras de interés que han sido descartadas por la población local debido a su temor a la incertidumbre y su motivación por oportunidad se incrementará.

\section{Metodología}

La evidencia para la realización de este estudio la proporcionan 468 emprendedores inmigrantes de primera generación, esto es, no nacidos en país diferente al que en el que actualmente residen, y asentados en 31 países europeos. En concreto, se hace uso de la información recopilada por la Encuesta Europea de Condiciones de Trabajo (6th EWCS; Eurofound, base de datos de 2015), que aportaba información sobre el inmigrante y su motivación emprendedora, entre otras variables de nivel micro y meso. Esta información fue complementada con otros conjuntos de datos que ofrecían información sobre las variables de nivel macro consideradas en este estudio (ej. el Proyecto Doing Business, Hofstede Insights). En concreto, las variables utilizadas en este estudio y sus medidas, se muestran en la Tabla 1. Los 31 países europeos en los que residen los inmigrantes emprendedores objeto de estudio son los siguientes: Austria, Bélgica, Bulgaria, Croacia, República Checa, Dinamarca, Estonia, Finlandia, Francia, Alemania, Grecia, Hungría, Irlanda, Italia, Letonia, Lituania, Luxemburgo, Malta, Países Bajos, Polonia, Portugal, Eslovaquia, Eslovenia, España, Suecia, Reino
Unido, Serbia, Turquía, Noruega, Suiza y Albania. Para llevar a cabo los análisis estadísticos que permitieran responder al objetivo planteado en este estudio, se hizo uso de la regresión lineal múltiple.

\section{Resultados}

Los resultados de este estudio (véase Tabla 2) encuentran que, además de los factores de nivel micro ampliamente considerados por los investigadores y a los que posteriormente haremos referencia (ej. género y nivel educativo del inmigrante, actitud personal emprendedora, control de comportamiento percibido), los factores de nivel macro, entre ellos las distancias lingüística y regulativa, así como los aspectos normativos de las instituciones en el país de acogida del inmigrante (en concreto, los valores nacionales de aversión a la incertidumbre), condicionan la motivación emprendedora de éste. Los factores de nivel meso, por su parte, no resultaron ser relevantes para condicionar la motivación emprendedora del inmigrante.

Adicionalmente, y de forma contraria a lo que esperábamos, hallamos que la mayor distancia regulativa incrementa la motivación por oportunidad. Ello sugiere que en casos en los que existen leyes económicas comunes o similares en los dos países implicados (de origen y de acogida), y los inmigrantes no son discriminados en el mercado laboral, la motivación por oportunidad se reduce. En la situación contraria, cuando la distancia regulativa es elevada y los inmigrantes son conscientes de las dificultades para integrarse en el mercado laboral en el país de destino, buscan oportunidades de negocio, por ejemplo, dentro de sus comunidades étnicas donde hallan una atmósfera o clima conocido y propicio para su actividad emprendedora. 
Tabla 1. Variables utilizadas en el estudio

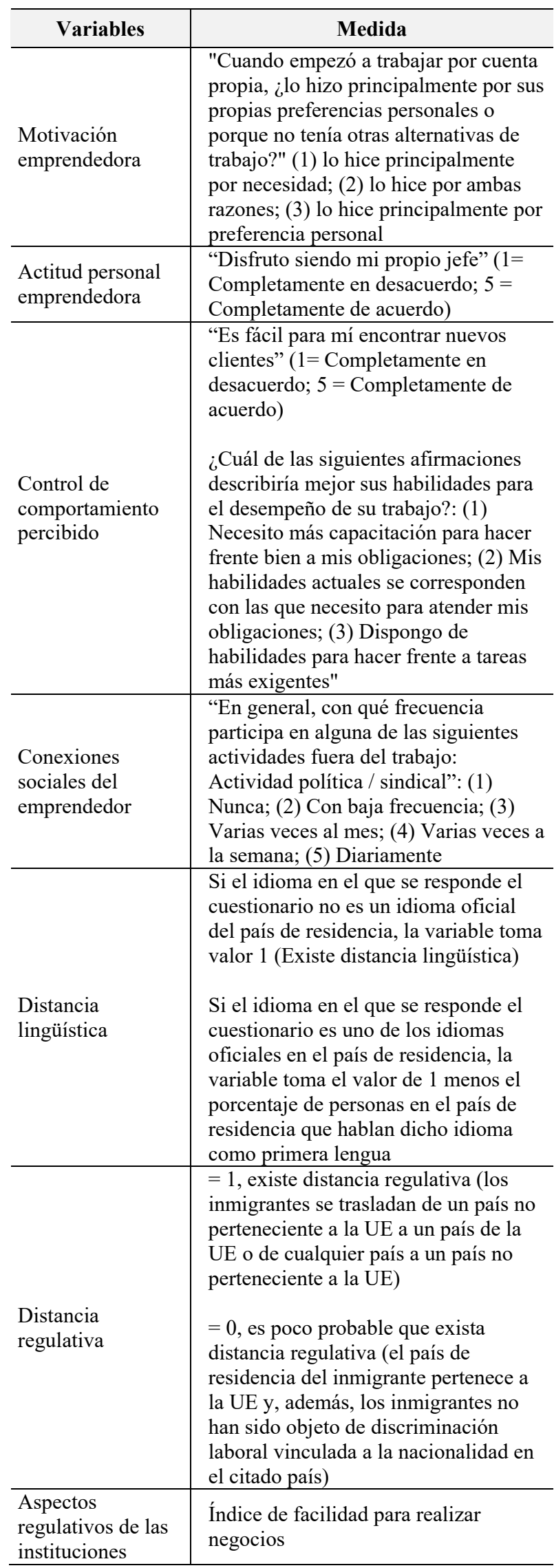

\begin{tabular}{l|l}
\hline \multicolumn{1}{c|}{ Variables } & \multicolumn{1}{c}{ Medida } \\
\hline $\begin{array}{l}\text { Aspectos } \\
\text { normativos de las } \\
\text { instituciones }\end{array}$ & $\begin{array}{l}\text { Valores culturales de evasión de } \\
\text { incertidumbre }\end{array}$ \\
\hline Género & 1=hombre; 2=mujer \\
\hline Edad & $\begin{array}{l}\text { Número de años de vida (variable } \\
\text { continua) }\end{array}$ \\
\hline Nivel educativo & $\begin{array}{l}\text { "iCuál es el nivel más alto de } \\
\text { educación que ha completado con } \\
\text { éxito?" (1) educación infantil y } \\
\text { educación primaria; (2) educación } \\
\text { secundaria, educación secundaria } \\
\text { superior y educación postsecundaria } \\
\text { no terciaria; (3) educación terciaria de } \\
\text { ciclo corto y licenciatura o } \\
\text { equivalente; (4) maestría o } \\
\text { equivalente; y (5) doctorado o } \\
\text { equivalente }\end{array}$ \\
\hline
\end{tabular}

Finalmente, y en lo que concierne a factores de nivel micro, nuestros resultados sugieren que, cuanto mayor es la atracción hacia el emprendimiento del inmigrante y mayor es su auto-eficacia percibida, más elevada será su motivación emprendedora por oportunidad. También encontramos que las mujeres inmigrantes establecidas en Europa tienen mayor motivación emprendedora por oportunidad que sus homólogos varones. En cuanto a nivel educativo, la motivación emprendedora por oportunidad resulta ser más elevada entre los inmigrantes con menor nivel de formación, probablemente debido a que aquellos con mayores estudios albergan una expectativa más alta de hallar un empleo por cuenta ajena de calidad cuando escogen un país europeo como lugar hacia el que emigrar, contemplando en menor medida el emprendimiento como opción profesional. 
Tabla 2. Resultados de los modelos estimados para analizar la motivación por oportunidad

\begin{tabular}{|c|c|c|}
\hline Variables & $\begin{array}{c}\text { Modelo 1 } \\
\text { Motivación por } \\
\text { oportunidad con } \\
\text { Índice de facilidad } \\
\text { para realizar } \\
\text { negocios } \\
\end{array}$ & $\begin{array}{c}\text { Modelo 2 } \\
\text { Motivación por } \\
\text { oportunidad con } \\
\text { Evasión de } \\
\text { incertidumbre }\end{array}$ \\
\hline $\begin{array}{l}\text { Género (1=hombre; } \\
2=\text { mujer) }\end{array}$ & $0,089 *$ & $0,086^{*}$ \\
\hline Edad & 0,053 & 0,053 \\
\hline Nivel educativo & $-0,130 * * *$ & $-0,114 * * *$ \\
\hline $\begin{array}{l}\text { Actitud emprendedora } \\
\text { personal }\end{array}$ & $0,218 * * *$ & $0,240 * * *$ \\
\hline $\begin{array}{l}\text { Control de } \\
\text { comportamiento }\end{array}$ & & \\
\hline $\begin{array}{l}\text { percibido: "Es fácil } \\
\text { para mi encontrar } \\
\text { nuevos clientes" }\end{array}$ & $0,119 * *$ & $0,214 * * *$ \\
\hline $\begin{array}{l}\text { Control de } \\
\text { comportamiento } \\
\text { percibido: "Mis }\end{array}$ & & \\
\hline $\begin{array}{l}\text { habilidades actuales } \\
\text { se ajustan bien a mis } \\
\text { responsabilidades en } \\
\text { el trabajo" }\end{array}$ & $0,097 * *$ & $0,093^{*}$ \\
\hline $\begin{array}{l}\text { Conexiones sociales } \\
\text { del emprendedor }\end{array}$ & $-0,027$ & $-0,037$ \\
\hline Distancia lingüística & $-0,099 *$ & $-0,088^{*}$ \\
\hline Distancia regulativa & 0,074 & $0,084^{*}$ \\
\hline $\begin{array}{l}\text { Índice de facilidad } \\
\text { para realizar negocios }\end{array}$ & 0,075 & --- \\
\hline $\begin{array}{l}\text { Evasión de } \\
\text { incertidumbre }\end{array}$ & --- & $0,116^{* *}$ \\
\hline $\begin{array}{l}\mathrm{R}^{2} \text { ajustada final } \\
F\end{array}$ & $\begin{array}{c}14,1 \% \\
7,368 * * *\end{array}$ & $\begin{array}{c}14,7 \% \\
7,810 * * * \\
\end{array}$ \\
\hline
\end{tabular}

Nota: las cifras en negrilla indican que las variables tienen un impacto estadísticamente significativo en la motivación por oportunidad del inmigrante emprendedor

$* p<.10 ; * * p<.05 ; * * * p<.01$.

\section{Conclusiones}

De los resultados de este trabajo derivan implicaciones para la formulación de políticas públicas y actuación de asociaciones privadas con el fin de promover la motivación por oportunidad del inmigrante emprendedor. En particular, nuestros resultados sugieren que, para promover tal motivación, deberían diseñarse e implantarse programas que ofrezcan al inmigrante incentivos para adquirir competencias en el manejo del idioma local; asimismo, debería facilitarse su acceso a cursos de formación empresarial al objeto de que incrementen su atracción hacia el emprendimiento y su percepción de autoeficacia emprendedora. Por otra parte, las organizaciones de apoyo al inmigrante radicadas en los países de acogida deberían promover la integración de éstos en redes sociales y en comunidades empresariales locales como medio para ayudarles a identificar oportunidades de negocio y a captar clientes.

\section{Referencias}

Ajzen, I. (1991). The theory of planned behaviour. Organizational Behavior and Human Decision Processes, 50(2), 179-211.

Azmat, F. (2010). Exploring social responsibility of immigrant entrepreneurs: Do home country contextual factors play a role? European Management Journal, 28(5), 377-386.

Bandura, A. (1997). Self-efficacy: The exercise of control. New York, Freeman.

Brewer, P.A. (2007). Operationalizing psychic distance: A revised approach. Journal of International Marketing, 15(1), 44-66.

Contín-Pilart, I., \& Larraza-Kintana, M. (2015). Do entrepreneurial role models influence the nascent entrepreneurial activity of immigrants? Journal of Small Business Management, 53(4), 1146-1163.

Hofstede, G. (1980). Culture and organizations. International Studies of Management \& Organization, 10(4), 15-41.

Kim, P.H., Wennberg, K., \& Croidieu, G. (2016). Untapped riches of meso-level applications in multilevel entrepreneurship mechanisms. Academy of Management Perspectives, 30(3), 273-291.

Kostova, T., \& Zaheer, S. (1999). Organizational legitimacy under conditions of complexity: The case of the multinational enterprise. Academy of Management Review, 24(1), 64-81.

Kroeber, A.L., \& Parsons, T. (1958). The concepts of culture and of social system. American Sociological Review, 23(5), 582-583.

Mariotti, S., \& Piscitello, L. (1995). Information costs and location of FDIs within the host country: empirical evidence from Italy. Journal of International Business Studies, 26(4), 815-841.

Mata, J., \& Alves, C. (2018). The survival of firms founded by immigrants: Institutional distance 
between home and host country, and experience in the host country. Strategic Management Journal, 39(11), 2965-2991.

Min, P.G., \& Bozorgmehr, M. (2003). United States: The entrepreneurial cutting edge. En Kloosterman, R. \& Rath, J. (Ed.), Immigrant entrepreneurs: Venturing abroad in the age of globalization (pp. 17-37), Oxford: Berg Publishers.

Reynolds, P.D., Bygrave, W.D., Autio, E., Cox, L.W., \& Hay, M. (2002). Global Entrepreneurship Monitor. 2002 Executive Report. Kansas City: Kauffman Foundation.
Scott, W.R. (1995). Institutions and organizations. Thousand Oaks: Sage.

Stenholm, P., Acs, Z.J., \& Wuebker, R. (2013). Exploring country-level institutional arrangements on the rate and type of entrepreneurial activity. Journal of Business Venturing, 28(1), 176-193.

Williams C.C. (2009). The motives of off-the-books entrepreneurs: Necessity- or opportunity-driven? The International Entrepreneurship and Management Journal, 5(2), 203-217. 


\title{
Is it possible to increase the opportunity motivation of immigrant entrepreneurs in Europe?
}

\author{
Antonia M. García-Cabrera ${ }^{1 \mathrm{a}}$, Ana M. Lucía-Casademunt ${ }^{\mathrm{b}}$, Laura Padilla-Angulo $^{\mathrm{c}}$ \\ ${ }^{a}$ Universidad de Las Palmas de Gran Canaria, Spain \\ ${ }^{b}$ Universidad de Málaga, Spain \\ ${ }^{c}$ Universidad Loyola Andalucía, Spain
}

\begin{abstract}
This study examines factors that condition opportunity motivation of immigrant entrepreneurs in 31 European countries. We find that distance in language between immigrants' country of residence and country of origin harms entrepreneurial opportunity motivation and that, at the same time, opportunity motivation is likely to benefit from both the normative aspects of institutions that reduce locals' opportunity motivation (cultural values of uncertainty avoidance) and the regulative distance (the dissimilarity between the laws and regulations). Implications for the formulation of public policies and actions of private associations to promote immigrant entrepreneurs' opportunity motivation derive from our work.
\end{abstract}

Keywords: immigrant entrepreneur, institutions, institutional distance, liability of foreignness.

JEL classification: J61, M13, M16.

Acknowledgement: This research was supported by the Spain's Economy, Industry and Competitiveness National Department [grant number ECO2016-80518-R].

Reference source: García-Cabrera, A. M., Lucía-Casademunt, A. M., \& Padilla-Angulo, L. (2020). Immigrants' entrepreneurial motivation in Europe: liabilities and assets. International Journal of Entrepreneurial Behavior \& Research, 25(8), 1707-1737.

\section{Introduction}

Immigrant entrepreneurship has commonly been associated with necessity-driven motivations, leading immigrants to consider entrepreneurship less difficult than wage employment. Immigrants with opportunitydriven motivations also exist and they identify and exploit business opportunities as a personal preference. Both types of drivers (necessity and opportunity) can also be present in a single individual's entrepreneurial motivation (Williams, 2009). As opportunity motivation is greater associated with economic growth and wealth in developed countries (Reynolds and others, 2002), it is of interest to understand factors that condition opportunity motivation of immigrants.

Most studies on immigrant entrepreneurship have focused their analysis at the micro level and so there is a need for understanding other variables at meso and macro levels. To fill this gap, we examine the influence on the immigrants' entrepreneurial motivation of: (1) macro-level variables such as the institutional distance (i.e., linguistic and regulative) between immigrants' country of residence and country of origin, and host country institutional aspects (i.e., easy-to-perform business index, uncertainty avoidance values); (2) meso-level variables (i.e., immigrant entrepreneurs' social connections); and (3) and micro-level variables (i.e., individual cognitive structures). Results show the key role that macro-level factors, particularly regulative and linguistic distance and social values in the country of residence, play in explaining immigrant entrepreneurial motivation in Europe.

${ }^{1}$ Corresponding author: antonia.garcia@ulpgc.es 


\section{Theoretical background}

Institutions can condition entrepreneurial motivation by facilitating and constraining the pursuit of business opportunities (Stenholm and others, 2013), and individuals who perceive business-friendly institutions will increase their opportunity-driven motivation. We argue that to understand immigrants' entrepreneurial motivation, the micro-level related to the individual, the meso-level linked to the social connection variables, and the macro-level related to their country of residence, must be considered.

Regarding the micro-level factors, we propose that immigrants with high perceived behavioural control, a proxy of self-efficacy (Bandura, 1997) and confidence in own entrepreneurial skills and abilities, as well as a strong entrepreneurial attitude, that is, who believe that the outcome of their entrepreneurial activity is desirable (Azjen, 1991), will have higher opportunity-driven motivation.

Referring to the meso-level factors, and based on Kim, Wennberg and Croidieu (2016), we consider social context factors in the host country as potential drivers of immigrants' entrepreneurial opportunity motivation because individuals do not behave independently but are integrated into a "relational system of interaction between individuals and communities" (Kroeber \& Parsons, 1958, p. 583). Accordingly, immigrants, through membership in associations, may access to useful information on laws in the country of residence, local cultural values and common firms' practices, which might help them identify entrepreneurial niches and increase their perception of the feasibility of entrepreneurship. Based on this, we might expect that the greater immigrants' participation in associations, the higher their entrepreneurial opportunity motivation.

Concerning macro-level factors, since the institutional context influences the development of entrepreneurship in host countries (e.g., Stenholm and others, 2013), we include them in our study. Scott (1995) distinguishes among regulative (laws), normative (cultural values) and cognitive (common practices used by firms) aspects of institutions. Individuals must know the requirements of each country's institutions and adapt their behaviour to them if they want to succeed (Scott, 1995) and immigrants in a host country will face the liability of foreignness as they do not know/understand such aspects of institutions (Mata \& Alves, 2018).

Institutional distance is the dissimilarity "between the regulatory, cognitive, and normative institutions of two countries" (Kostova \& Zaheer, 1999, p. 71) and, in businesses, it mainly concerns the impediments to information flows between people from different countries (Brewer, 2007).

First, regulative distance are the difficulties in becoming familiar with the administrative, political, or economic systems in the host country, conditioning immigrants' ability to acquire knowledge about the host country (Brewer, 2007). In this view, Azmat (2010) argues that immigrant entrepreneurs are likely to find it difficult to adjust to the laws and regulations in the host country if they have been exposed to a weak institutional environment in their home country (e.g., if they come from developing countries, usually with less stable and solid regulatory frameworks). When the regulative aspects of institutions in the host country are similar to those in immigrants' country of origin, -for example, similar economic laws-, the informational asymmetry faced by immigrants is reduced (Mata \& Alves, 2018) and so will liabilities of foreignness. This lower regulative institutional distance allows them to see entrepreneurial activities as feasible and desirable as do natives and will positively impact their opportunity-driven motivation. 
Second, culture (i.e., normative institutions) also differs among countries (Hofstede, 1980) and we expect that greater cultural distances may result in more difficulty adapting to the local conditions. To this respect, some authors find that shared language (as part of a culture) reduces cultural distance (Mariotti \& Piscitello, 1995). Thus, we can also expect that the lower the distance between immigrants' country of residence and country of origin in language (in the most favourable case, in host country' all regions the first language is that of the immigrant's country of origin), the greater their opportunity motivation.

In addition, although literature emphasizes that foreignness is a liability that leads immigrants to become entrepreneurs out of necessity, some author have found that foreigners may become entrepreneurs driven by opportunity reasons more than locals. It suggests that immigrants may be more effective than locals in searching for business opportunities (foreignness as an asset, Min and Bozorgmehr, 2003). To respect, we could expect that individuals who perceive a business-friendly regulatory environment could feel their latent opportunity motivation. In other words, the greater the extent to which the regulative aspects of institutions support business activities in the host country, the higher immigrant entrepreneurs' opportunity motivation.

Finally, the normative aspects of institutions -i.e., socially shared assumptions and normative expectations- can also condition individuals' entrepreneurial motivation. For instance, societies low in uncertainty avoidance (i.e., extent to which members of a culture fear uncertain or unknown situations) are ready to assume the risks and exploit identified opportunities (Hofstede, 1980), but societies high in uncertainty avoidance fear failure, and avoid assuming risks. In this line, we believe that when national culture harms entrepreneurial opportunity motivations, for example, in countries where uncertainty avoidance values are high, immigrants, compared to locals, will be relatively isolated from the negative stimulus of the cultural environment (Contín-Pilart \& Larraza-Kintana, 2015) and may perceive fruitful business opportunities not well exploited by locals. Accordingly, the greater the normative aspects of institutions that harm entrepreneurial activities in the country of residence (e.g., uncertainty avoidance national values), the greater immigrant entrepreneurs' opportunity motivation.

\section{Methodology}

We analyse 468 first-generation immigrant entrepreneurs settled in 31 European countries using data from the European Working Conditions Survey (6th EWCS; Eurofound, 2015 database) combined with other datasets to derive the macro-level variables (i.e., the Doing Business Project; Hofstede Insights). Specifically, variables used in this study and their measurement are shown in Table 1. The 31 European countries included were: Austria, Belgium, Bulgaria, Croatia, Czech Republic, Denmark, Estonia, Finland, France, Germany, Greece, Hungary, Ireland, Italy, Latvia, Lithuania, Luxembourg, Malta, the Netherlands, Poland, Portugal, Slovakia, Slovenia, Spain, Sweden, the UK, Serbia, Turkey, Norway, Switzerland, and Albania. Multiple linear regression analyses were used to carry out estimations and answer the research question of the present study.

\section{Results}

Results (see Table 2) find that in addition to micro-level factors (i.e., gender, level of education, entrepreneurial personal attitude and perceived behavioural control), macro-level factors, including regulative and linguistic distance, together with the normative aspects of institutions (uncertainty avoidance national values), affect immigrants' entrepreneurial 
motivations. Linguistic distance negatively affects immigrants' entrepreneurial opportunity motivation and immigrants are more likely to be driven by opportunity motivation in host countries where uncertainty avoidance values harm the local population's will to become entrepreneurs. However, meso-level factors were not relevant to condition immigrants' entrepreneurial motivation.

\section{Table 1. Variable measurement}

\begin{tabular}{|c|c|}
\hline Variables & Measurement \\
\hline $\begin{array}{l}\text { Entrepreneurial } \\
\text { motivation }\end{array}$ & $\begin{array}{l}\text { "When you became self-employed, was } \\
\text { it mainly through your own personal } \\
\text { preference or because you had no other } \\
\text { alternatives for work?", where } 1 \text { means } \\
\text { mainly through necessity, } 2 \text { means for } \\
\text { both reasons, and } 3 \text { means mainly } \\
\text { through personal preference }\end{array}$ \\
\hline $\begin{array}{l}\text { Entrepreneurial } \\
\text { personal attitude }\end{array}$ & $\begin{array}{l}\text { "I enjoy being my own boss" }(1= \\
\text { Strongly disagree; } 5=\text { Strongly agree })\end{array}$ \\
\hline & $\begin{array}{l}\text { "It is easy for me to find new } \\
\text { customers" ( } 1=\text { Strongly disagree; } 5= \\
\text { Strongly agree })\end{array}$ \\
\hline $\begin{array}{l}\text { Perceived } \\
\text { behavioural } \\
\text { control }\end{array}$ & $\begin{array}{l}\text { "Which of the following statements } \\
\text { would best describe your skills in your } \\
\text { own work?: (1) I need further training } \\
\text { to cope well with my duties, (2) My } \\
\text { present skills correspond well with my } \\
\text { duties, or (3) I have the skills to cope } \\
\text { with more demanding duties" }\end{array}$ \\
\hline $\begin{array}{l}\text { Social } \\
\text { connections of } \\
\text { entrepreneurs }\end{array}$ & $\begin{array}{l}\text { "In general, how often are you involved } \\
\text { in any of the following activities } \\
\text { outside work: Political/trade union } \\
\text { activity". (1) Never, (2) Less often, (3) } \\
\text { Several times a month, (4) Several } \\
\text { times a week, or (5) Daily. }\end{array}$ \\
\hline & $\begin{array}{l}\text { If the language in which the } \\
\text { questionnaire is answered is not an } \\
\text { official language of the host country, it } \\
\text { will be } 1 \text { (Linguistic distance exists) }\end{array}$ \\
\hline $\begin{array}{l}\text { Linguistic } \\
\text { distance }\end{array}$ & $\begin{array}{l}\text { If the language in which the } \\
\text { questionnaire is answered is one of the } \\
\text { official languages in the host country, it } \\
\text { will be } 1 \text { minus the percentage of } \\
\text { people in the host country with this } \\
\text { language as their first language }\end{array}$ \\
\hline $\begin{array}{l}\text { Regulative } \\
\text { distance }\end{array}$ & $\begin{array}{l}=1, \text { Regulative distance exists } \\
\text { (immigrants move from a non-EU } \\
\text { country to one EU country or move } \\
\text { from any country to a non-EU country) } \\
=0 \text {, Regulative distance unlikely exists } \\
\text { (the belonging of the immigrant's } \\
\text { country of residence to EU AND } \\
\text { immigrants have not been subjected to }\end{array}$ \\
\hline
\end{tabular}

\begin{tabular}{|c|c|}
\hline Variables & Measurement \\
\hline & $\begin{array}{l}\text { labour discrimination linked to } \\
\text { nationality in the country of residence) }\end{array}$ \\
\hline $\begin{array}{l}\text { Regulative } \\
\text { aspects of } \\
\text { institutions }\end{array}$ & Ease of Doing Business Index \\
\hline $\begin{array}{l}\text { Normative } \\
\text { aspects of } \\
\text { institutions }\end{array}$ & Uncertainty avoidance cultural values \\
\hline Gender & $1=$ male; $2=$ female \\
\hline Age & $\begin{array}{l}\text { Number of years of life (continuous } \\
\text { variable) }\end{array}$ \\
\hline $\begin{array}{l}\text { Level of } \\
\text { Education }\end{array}$ & $\begin{array}{l}\text { "What is the highest level of education } \\
\text { or training that you have successfully } \\
\text { completed?" (1) early childhood } \\
\text { education and primary education; (2) } \\
\text { secondary education, upper secondary } \\
\text { education and post-secondary non- } \\
\text { tertiary education; (3) short-cycle } \\
\text { tertiary education and bachelor or } \\
\text { equivalent; (4) master or equivalent; } \\
\text { and (5) doctorate or equivalent }\end{array}$ \\
\hline
\end{tabular}

Furthermore, we unexpectedly find that greater regulative distance increases opportunity motivation. Therefore, in cases where similar or common economic laws exist across two countries and immigrants are not discriminated at work, opportunity motivation declines. In contrast, in cases of higher regulative distance, with immigrants being aware of the difficulties in integrating into the labour market, they will seek business opportunities, for example, within their ethnic communities.

Finally, and concerning micro-level factors, our results suggest that the higher the immigrant's entrepreneurial attraction and selfefficacy, the stronger the entrepreneurial opportunity motivation. We also found that immigrant females located in Europe have higher opportunity-driven entrepreneurial motivation than males, while the higher immigrants' level of education is, the lower their opportunity-driven entrepreneurial motivation. This is probably because those immigrants with higher level of education have an upper expectation of finding a quality job in Europe, and so they consider entrepreneurship as a professional career to a lesser extent. 
Table 2. Results of Estimated Models Examining Opportunity Motivation

\begin{tabular}{|c|c|c|}
\hline Variables & $\begin{array}{c}\text { Model 1 } \\
\text { Opportunity } \\
\text { motivation with } \\
\text { Ease of Doing } \\
\text { Business Index } \\
\end{array}$ & $\begin{array}{c}\text { Model 2 } \\
\text { Opportunity } \\
\text { motivation with } \\
\text { Uncertainty } \\
\text { Avoidance } \\
\end{array}$ \\
\hline $\begin{array}{l}\text { Gender }(1=\text { male; } \\
2=\text { female })\end{array}$ & $0.089 *$ & $0.086^{*}$ \\
\hline Age & 0.053 & 0.053 \\
\hline Level of Education & $-0.130 * * *$ & $-0.114 * * *$ \\
\hline $\begin{array}{l}\text { Entrepreneurial personal } \\
\text { attitude }\end{array}$ & $0.218 * * *$ & $0.240 * * *$ \\
\hline $\begin{array}{l}\text { Perceived behavioural } \\
\text { control: "It is easy for } \\
\text { me to find new }\end{array}$ & $0.119 * *$ & $0.214 * * *$ \\
\hline customers" & & \\
\hline $\begin{array}{l}\text { Perceived behavioural } \\
\text { control: "My present } \\
\text { skills correspond well } \\
\text { with my duties at work" }\end{array}$ & $0.097 * *$ & $0.093 *$ \\
\hline $\begin{array}{l}\text { Social connections of } \\
\text { entrepreneurs }\end{array}$ & -0.027 & -0.037 \\
\hline Linguistic distance & $-0.099 *$ & $-0.088 *$ \\
\hline Regulative distance & 0.074 & $0.084 *$ \\
\hline $\begin{array}{l}\text { Ease of Doing Business } \\
\text { Index }\end{array}$ & 0.075 & --- \\
\hline Uncertainty avoidance & --- & $0.116 * *$ \\
\hline $\begin{array}{l}\text { Final adjusted } \mathbf{R}^{2} \\
F\end{array}$ & $\begin{array}{c}14.1 \% \\
7.368 * * *\end{array}$ & $\begin{array}{c}14.7 \% \\
7.810 * * *\end{array}$ \\
\hline
\end{tabular}

\section{Conclusions}

According to our results, some public policies and actions of private associations to promote immigrant entrepreneurs opportunity motivation should be promoted. Specifically, our results suggest that to promote immigrants' opportunity entrepreneurial behaviour, programs should give incentives to immigrants to gain local language skills and facilitate them access to business training to increase their entrepreneurial attraction and their entrepreneurial self-efficacy. In addition, host country supporting organizations should promote social networking between immigrant entrepreneurs and local business communities to help immigrants find new customers and identify opportunities.

\section{Referencias}

Ajzen, I. (1991). The theory of planned behaviour. Organizational Behavior and Human Decision Processes, 50(2), 179-211.

Azmat, F. (2010). Exploring social responsibility of immigrant entrepreneurs: Do home country contextual factors play a role? European Management Journal, 28(5), 377-386.

Bandura, A. (1997). Self-efficacy: The exercise of control. New York, Freeman.

Brewer, P.A. (2007). Operationalizing psychic distance: A revised approach. Journal of International Marketing, 15(1), 44-66.

Contín-Pilart, I., \& Larraza-Kintana, M. (2015). Do entrepreneurial role models influence the nascent entrepreneurial activity of immigrants? Journal of Small Business Management, 53(4), 1146-1163.

Hofstede, G. (1980). Culture and organizations. International Studies of Management \& Organization, 10(4), 15-41.

Kim, P.H., Wennberg, K., \& Croidieu, G. (2016). Untapped riches of meso-level applications in multilevel entrepreneurship mechanisms. Academy of Management Perspectives, 30(3), 273-291.

Kostova, T., \& Zaheer, S. (1999). Organizational legitimacy under conditions of complexity: The case of the multinational enterprise. Academy $O f$ Management Review, 24(1), 64-81.

Kroeber, A.L., \& Parsons, T. (1958). The concepts of culture and of social system. American Sociological Review, 23(5), 582-583.

Mariotti, S., \& Piscitello, L. (1995). Information costs and location of FDIs within the host country: empirical evidence from Italy. Journal of International Business Studies, 26(4), 815-841.

Mata, J., \& Alves, C. (2018). The survival of firms founded by immigrants: Institutional distance between home and host country, and experience in the host country. Strategic Management Journal, 39(11), 2965-2991.

Min, P.G., \& Bozorgmehr, M. (2003). United States: The entrepreneurial cutting edge. En Kloosterman, R. \& Rath, J. (Ed.), Immigrant entrepreneurs: Venturing 
abroad in the age of globalization (pp. 17-37), Oxford: Berg Publishers.

Reynolds, P.D., Bygrave, W.D., Autio, E., Cox, L.W., \& Hay, M. (2002). Global Entrepreneurship Monitor. 2002 Executive Report. Kansas City: Kauffman Foundation.

Scott, W.R. (1995). Institutions and organizations. Thousand Oaks: Sage.
Stenholm, P., Acs, Z.J., \& Wuebker, R. (2013). Exploring country-level institutional arrangements on the rate and type of entrepreneurial activity. Journal of Business Venturing, 28(1), 176-193.

Williams C.C. (2009). The motives of off-the-books entrepreneurs: Necessity- or opportunity-driven? The International Entrepreneurship and Management Journal, 5(2), 203-217. 